\title{
"I believe in faking": The Dilemma of Photographic Realism at the Dawn of Photojournalism
}

\section{Andie Tucher}

To cite this article: Andie Tucher (2017): "I believe in faking": The Dilemma of Photographic Realism at the Dawn of Photojournalism, Photography and Culture, DOI: 10.1080/17514517.2017.1322397

To link to this article: http://dx.doi.org/10.1080/17514517.2017.1322397

里 Published online: 01 Jun 2017.

Submit your article to this journal 저

View related articles

View Crossmark data \lceil 


\section{Photography \& Culture}

Volume 10-Issue 2 June 2017

pp. 1-20

DOI:

10.1080/17514517.2017.1322397

Reprints available directly from the publishers

Photocopying permitted by license only

(C) 2017 Informa UK Limited, trading as Taylor \& Francis Group

\section{"I believe in faking": The Dilemma of Photographic Realism at the Dawn of Photojournalism}

\section{Andie Tucher}

\begin{abstract}
From about 1885 to 1910 , the concept of the "fake" was an integral part of an ongoing debate in the USA over how best to represent reality for a mass journalistic audience. Nothing like the nefarious fraud its name might suggest, the term generally referred to the modest embellishment, invention, or correction of details in a story or a photograph to make it seem more vivid and truer to life. In both the newspaper press and the world of photography, some practitioners initially embraced the tactic as both useful for the practitioner and beneficial to the public. After the growing condemnation of the fake in the newspaper world helped to cement the increasing dominance of the professionalized journalist, in photography a vigorous debate carried out in the trade and popular press over the propriety and consequences of manipulating images helped to mark the boundaries of the emerging profession of photojournalism. The debate resonates to this day.
\end{abstract}

Keywords: photojournalism, journalism history, realism, fake, professionalization

Photojournalism was born and newspaper journalism came of age at exactly the same time, around the end of the nineteenth and the beginning of the twentieth centuries. Both photographs and newspapers had been around much longer, of course, but in the United States they took their definitive and recognizably modern shapes as professionalized practices during the age of "the real thing" - the era of intense and widespread interest in authenticity, in science, in objectivity, in the literal and verifiable fact, and in the representation of life as it truly was (Roggenkamp 2005, 20-2l; see also Orvell 1989; Shi 1995).

Truth-telling is always complicated, however, and even at this high tide of Americans' romance with realism, opinions varied widely about the best way to represent real life. In 1896, for instance, Adolph Ochs bought the moribund New York Times and soon turned it into a pioneer of what has come to be called the "information mode" of independent, 
objective, fact-centered reporting. At the exactly the same time, however, William Randolph Hearst's New York Journal, Joseph Pulitzer's New York World, and other so-called yellow papers were drawing huge readerships with screaming headlines, gaudy illustrations, sensationalism, and splash, all the while insisting that their approach - summed up by scholars as the "story" mode - also produced perfectly accurate reporting (Schudson 1978 , 88-120). The boundaries between fact and fiction were growing ever blurrier, as novelists strove for the authority of the reporter and reporters quit their jobs to embrace the freedom of the novelist (Connery 20 I I; Roggenkamp 2005). Photographs remained nearly invisible in the mass newspaper press throughout the 1880s and 1890s as many readers and editors resisted what they considered the dead mechanical literalness of the photograph compared to the nuance possible in engraved illustrations produced by the human hand and eye (Barnhurst and Nerone 200 I, I I I-39; Carlebach 1997, II-15; Harris 1990; Schuneman 1965). And outside of the mass press, the conventions of photographic realism had become tensile enough to accommodate under that rubric images of everything from pudgy children sprouting angels' wings to the crucifixion of Jesus (Novak 2008, I-5; Orvell 1989,73-102).

From about 1885 to 1910, as part of their efforts to establish conventions for the realistic rendering of the world for a mass audience, first newspaper journalists and then photographers thrashed their way through a complex and consequential entanglement with another cultural mode of expression that was nearly as distinctive a product of its time as the "real thing" and that, to some, offered an approach that seemed even truer to life than one that was mindlessly literal. It was known, openly and cheerfully, as the fake. By the late 1890s the brief romance between newspaper reporters and the fake was ending, its widespread repudiation having come to symbolize the growing dominance of the professionalized journalist (Tucher 2013). Yet even as newspaper journalists were condemning the fake to ignominy and as photographs were becoming a routine presence for the first time in the daily press, many commercial photographers were deliberately adopting the now-discredited term to describe their own relationship with reality.

An exploration of how the debate over photographic faking played out in the practical, everyday terms of the general and trade press, not in the sometimes airless precincts of photography theory, offers suggestive insights into evolving understandings about the differences between word and image, art and reality, and truth and falsehood at the moment that both print journalism and photojournalism were becoming modern. In this century-old debate about faking and photography, moreover, will be heard clear echoes of the urgent current conversations about the meaning of "real" and "authentic" as applied to infinitely manipulable digital images and about the role and obligation of the photojournalist in a Photoshoppable world.

\section{Newspaper faking, 1880s-90s: a brief background}

When in the mid-1880s the term "fake" began to creep into professional manuals, reporters' memoirs, and the nascent journalistic trade press, it was new to polite company, having previously been confined to the disreputable precincts of the theater and the underworld (Tucher 2013, 100). But in its fresh application to newspaper work the word conveyed a meaning more benevolent than nefarious. By "not exactly lying," as one indulgent observer put it in a pioneering trade journal called The Writer (Hills I887, 154) - by drawing on their imaginations or using adroit sleight-of-hand to supply stories with colorful details that they had not managed to note on the spot, that they hadn't arrived in time to observe, or that simply made the story more vivid - reporters could portray real life in ways that were both appealing and persuasive.

Under certain conditions, in fact, faking was not just "legitimate," it was "an almost necessary adjunct of daily journalism" that worked for the public's own good (Bain 1894, 274). How else, 
journalists demanded, could they responsibly satisfy their readers' desire for full, realistic accounts of the wedding of the secretary of state's daughter, which had been thoughtlessly scheduled for less than an hour before the afternoon deadline (274-76), or the great tornado in St. Louis, which had wrought such havoc on the telegraph wires that no eyewitness descriptions could get through ("Spectator" 1901, 438)? Other reporters argued that spicing up a story with colorful, dramatic, or lively touches was a positive service for their readers. Who wouldn't prefer to read that a stodgy professor had been enticed into indiscretion by a "bright and charming brunette of sixteen" instead of the "washed-out blonde" of 23 he actually fell for (Hills 1887, I 55)? Certainly faking should be "confined to non-essentials," as a handbook for young journalists advised in 1894, and should be "done by one who has in him at least the desire to represent the truth" (Shuman I894, 122). But "truth in essentials, imagination in non-essentials, is considered a legitimate rule of action in every office," the handbook concluded, cautioning reporters against "fall[ing] into the dull and prosy error of being tiresomely exact about little things like the minutes and seconds or the state of the atmosphere or the precise words of the speaker. A newspaper is not a mathematical treatise" (123).

Embellishment and imprecision, of course, were nothing new in the annals of journalism, but reporters had rarely talked about it openly. Now some of them were actually professing publicly that embellishment and imprecision produced better journalism than any "bare recital of facts" ever could ("Spectator" I901, 437). Other benefits of the practice were acknowledged more quietly: it was profitable for publishers looking to boost their circulation, it was lucrative for stringers who were paid by the column inch (Walker 1898), and it was plain fun, a creative escape for the bored shoeleather reporter - and perhaps for the reader as well. Since many nineteenth-century newspapers, particularly local ones, routinely offered an indiscriminate cornucopia of reading matter ranging from timely intelligence about current events to travelers' letters, jokes, serialized novels, poetry, hoaxes, and tall tales, readers had no expectation that everything they encountered in newsprint was literally, factually true. Experienced readers understood the cues, knew how to categorize what they read, and would not often have been either surprised or offended by a paragraph more artful than was strictly necessary (Tucher 200 I).

Yet the journalistic fakers had always been outnumbered by their critics, and by the late 1890s, as the new, fact-centered, rigorously observed "information" mode took firm root in the newspaper world and journalists on papers of that kind began to view themselves and their work as "professional" (Schudson 1978, 61-87; Forde and Foss 2012; Tucher 2006), many news workers came to realize that boasting about how they had played with facts no longer seemed endearing. Some reporters, of course, continued to embellish and invent, with or without their editors' complicity, and simply denied that they had done so. But even the editors of the sensational yellow press began ostentatiously repudiating the journalistic fake. Though they hadn't abandoned the entertaining "story" mode that had brought them such success, they too, as Joseph Pulitzer's New York World insisted on signs plastered around its newsrooms, were devoted to "Accuracy, Accuracy, Accuracy!' (Dreiser 2000, 625). Increasingly applied as the term of choice for journalistic indiscretions of all stripes, from the padding of telegraphic dispatches to the manufacture of news by PR men, the useful word "fake" soon began to spiral out of the newspaper world to enter the general discourse as well. Soon the "fake" was turning up in contexts and situations involving just about any kind of manipulation or deception: fake art, faked prizefights, fake butter, fake wills (Tucher 2013, 105-106). By the end of the nineteenth century the very word "fake" had, it seems, entirely lost its brief bloom.

The more serious newspapers, meanwhile, were signaling both their commitment to factcentered reporting and their clear differences from the traditions of the yellow press with new 
approaches to writing as well as new techniques of observation, jettisoning the verbiage as well as the jokes and pranks to embrace a lean, neutral, unadorned style. Although freewheeling types like Lincoln Steffens ([1931] 2005, 179) protested the mandate to "report the news as it happened, like machines, without prejudice, color, and without style; all alike," the mechanistic new mode was intended to assure readers that they were receiving pure information - facts that had been gathered through scientific observation, had been recorded with dispassion, and were unadulterated by opinion, guesswork, or any other merely human quality. A mathematical treatise, in fact, was very much what newspaper style was supposed to sound like. It was not supposed to sound like the unaccountable, unpredictable burst from someone's very human imagination that went by the name of "fake" and that had become impossible to defend any longer as truer to life.

\section{Photography and the "literal truth"}

Except in photography. Around the beginning of the twentieth century - at exactly the same time that respectable newspaper journalists were roundly condemning the fake, at the same time the wider public was adopting the term into the general vocabulary of deception and manipulation, and at the same time that photographs were becoming an accepted feature of the daily mass press - some commercial and artistic photographers were starting over at the beginning by enthusiastically importing that same now-disreputable word into their own debate, strikingly similar in tone and message to the one the newspaper people had just put behind them, over the increasingly complex relationship between representation and reality. Not only did they deploy the term with the same jaunty and possessive tone the reporters had recently used; like the newspaper journalists before them, they too were attempting to justify a range of tactics whose main goal was not to deceive customers, not to make an exact replication of reality, but to bestow on their customers a better reality, one they could and would appreciate. The point was not necessarily that faking should "make the photograph more truthful to Nature," as one of them put it, "but that it should seem more truthful, which is by no means the same thing" (Hinton I898, 70). As another photographer defiantly declared in an address before the Photographers' Association of America, "I believe in faking, I admire legitimate faking, successful faking, faking that produces the results desired," and in his peroration he urged his colleagues to overcome the "falseness of ultra-realism" to attain "not literal, but spiritual and eternal truth" (Parkinson 1902, 522, 523). He is reported to have brought down the house.'

The term for the practice may have been new, but at that point overcoming the literal truth was old hat for photographers of all stripes. The invention that not so long ago had dazzled Edgar Allan Poe (1840) with its capacity to present "a more absolute truth" soon came to be understood instead as expressing a wide range of more qualified truths whose precise relationship to reality could be open to debate. Among the most intense of those mid-century debates was the one surrounding William Mumler's entrepreneurial "spirit photographs," which allegedly showed phantoms of the dearly departed leaning palely over the shoulders of their mourners. Many observers (including a string of expert witnesses testifying against Mumler at his hearing in 1869 on charges of larceny and fraud) condemned the photographs as both swindles and shams, created through cunning mechanical manipulations for the express purpose of deceiving their sitters. Plenty of those sitters, however, for instance John J. Glover of Quincy, Massachusetts (Figure I), whose sturdy, unruffled presence and reassuringly conventional pose seemed to lend weight to his insistence that the ancient lady wafting indistinctly behind him was Mother, deliberately chose to trust their imaginations and their emotions rather than the experts to judge what was real (Kaplan 2008, I 19; Leja 2004, 31 ).

Other debates concerned the purposes and effects of the popular genre of staged or narrative 


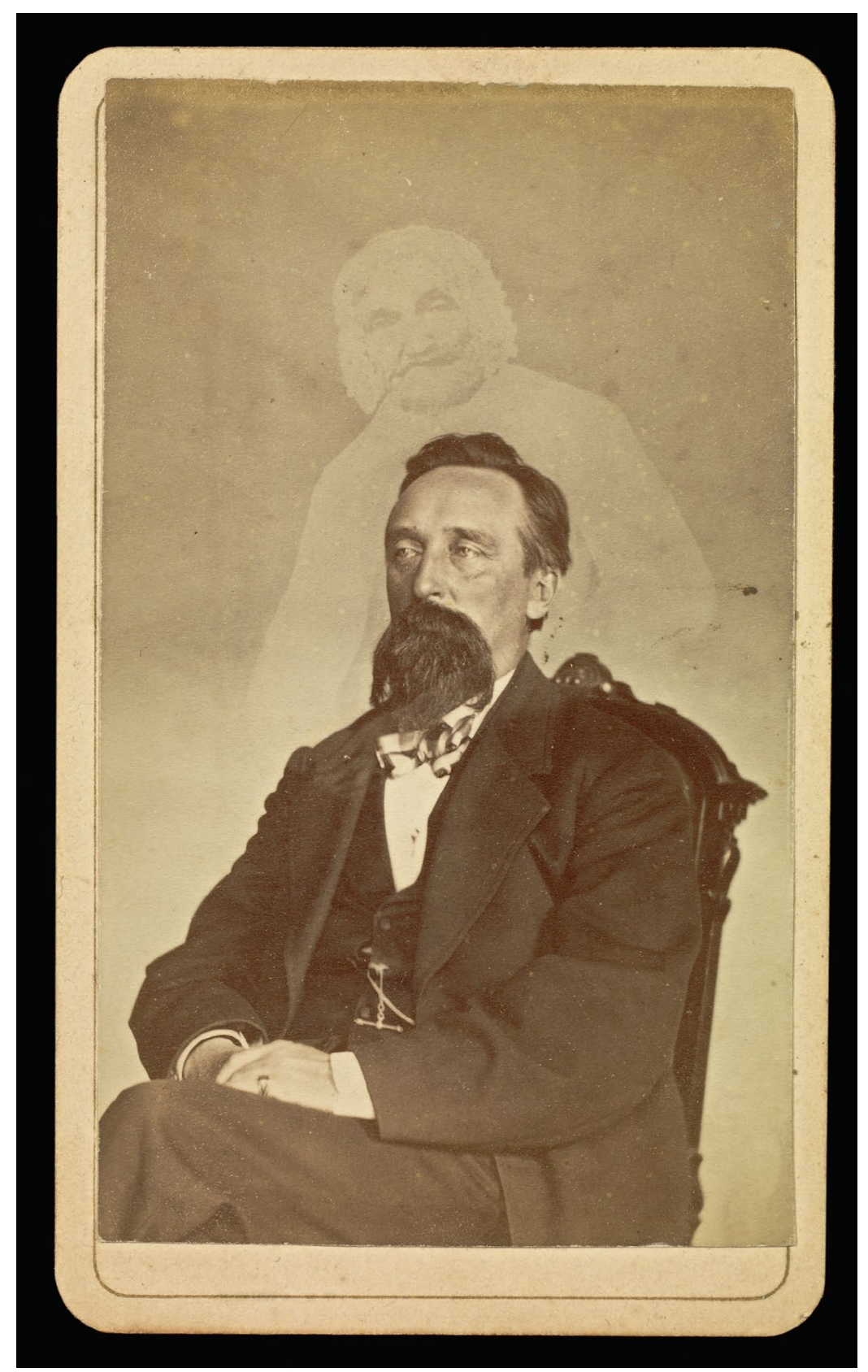

Figure I. William H. Mumler, John J. Glover. Albumen silver print, 1862-75. J. Paul Getty Museum, Los Angeles. Digital image courtesy of the Getty Open Content Program. 
photography, which often featured costumed characters in elaborately arranged tableaux portraying fairy-tale characters, historical events, or sentimental scenes. While few viewers would have seen such photographs as truthful reproductions of authentic happenings in real life, they did expect them to look like truthful reproductions of authentic happenings in real life; they expected, in other words, that images of Red Riding Hood or the dying maiden should conform to generally accepted conceptual, aesthetic, and dramatic conventions. That was problematic for F. Holland Day when, wild of hair and scrawny from fasting, he played the starring role in his own reenactments of the Crucifixion (Figure 2). Some critics blasted Day's proto-selfies as blasphemous, but to others the images were simply artificial and unpersuasive, too obviously just a guy in a loincloth pretending to be Christ (Orvell 1989, 85-88; Jussim 1981, 122-35).

Meanwhile, Alfred Stieglitz and other pictorialists were insisting that photography was just as capable of artistic expression as painting was, and commercial photographers were developing an array of techniques offering the finicky or the fumble-fingered a second chance at photographic perfection. They could, for instance, cover scratches left on the print during developing, or they could correct the tone of the sky (which in contemporary processes usually printed stark white) by pasting dark paper over parts of the negative. At the same time nature now had a second chance, too, as photographers discovered how to touch up their negatives or their prints with pencils, brushes, sponges, and stumps. Some purists viewed the practice of manipulating images "not only with regret, but disgust"; it was, they said, nothing more than a refuge for the incompetent (Snelling 1872, 7I). But for many who made their living with the camera, retouching was simply "the act of improving and beautifying photographic portraits," a way to satisfy sitters who preferred - even expected - to be relieved of wrinkles, blemishes, and wayward curls (Morgeneier 1873). "There is no use in trying to do away with retouching," wrote one worldweary portraitist. Customers

pay the money for the pictures, or photographs, and they have a right to say how they will have them finished ... It would seem to me that if a person of sixty years wants for any reason to be made to look as near thirty as possible, the nearer the photographer can come to hitting the mark the better it will be for him. The main thing, I take it, is that the photographer, being in the business not for the love of it so much as for a living, had best get his living in the easiest way possible for himself and with the most satisfaction to his patrons (Hickmott 1897, 82-83; see also Taft 1938, 324-31).

Just as they did with the nineteenth-century newspaper, therefore, people had a complicated and contingent understanding of the relationship between a photograph and reality. Photographs could be literal, or artistic, or fantastic; they could document, or bamboozle, or tease; they could reveal the spirit hovering over your shoulder or conceal the birthmark spreading over your cheek. Like newspapers in general, photographs in general were seen to have a special and intimate relationship with the real and the true. But like any given newspaper item, any individual photograph might be offering its beholders something rather different than the mimetic reproduction of actual scenes or events. The Victorians, writes Miles Orvell $(1989,77)$,

luxuriated in the many diverse forms [photography] might take, one moment celebrating its capacity for a seemingly literal imitation of reality and the next its use as a vehicle for fantasy and illusion ... The realism of Victorian photography is properly understood as an "artificial realism," in which the image offers the viewer a representation of reality, a typification, a conscious simulacrum - though a simulacrum that elicited a willing suspension of disbelief. 


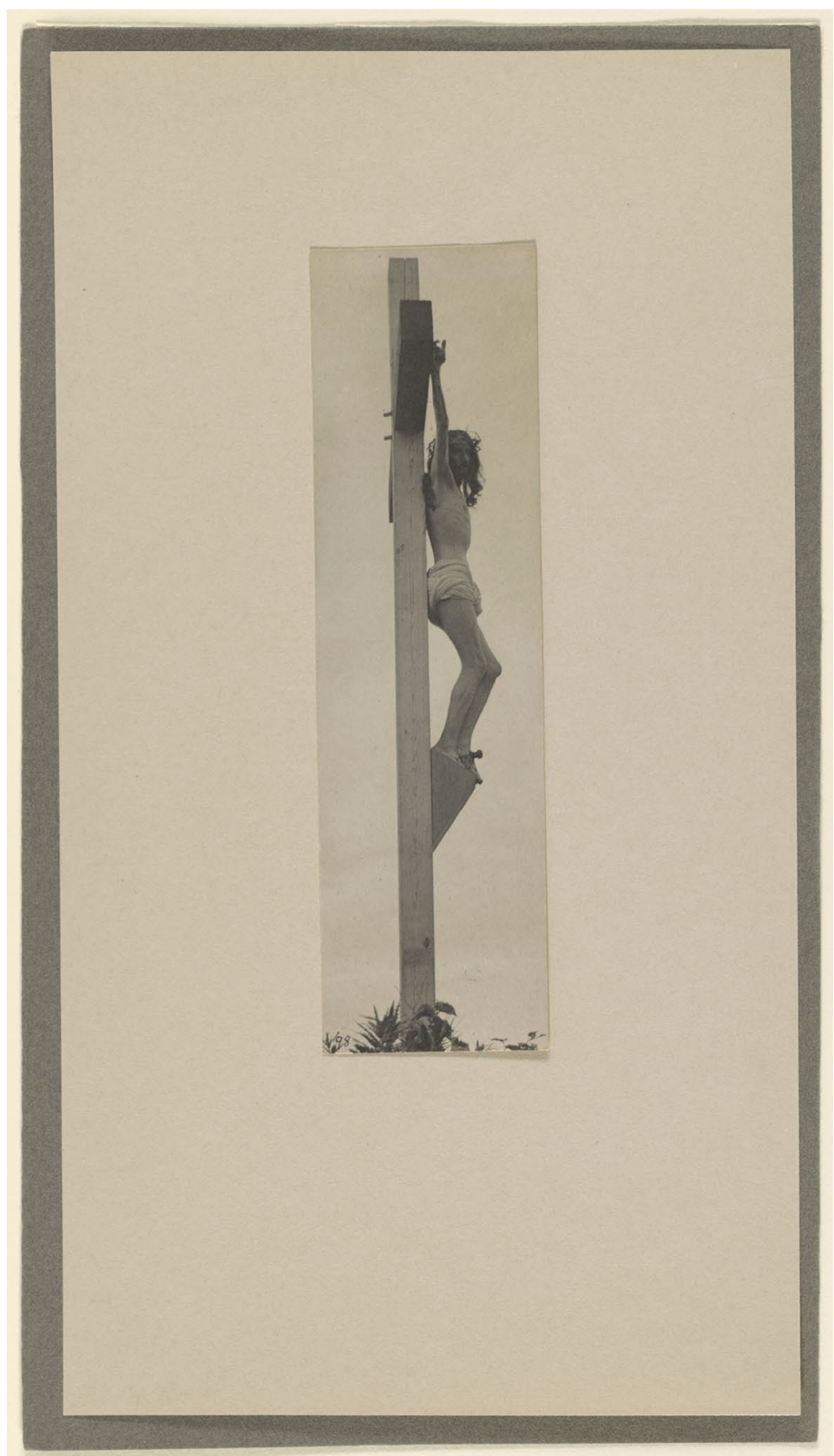

Figure 2. F. Holland Day, [Crucifixion, Profile, Right]. Platinum print, I898. Library of Congress, Washington, D.C. 


\section{"News" photographs before photojournalism}

Among those many diverse forms of Victorian photography, according to some historians and other writers, was the genre they refer to with the deliberately anachronistic term "photojournalism" (e.g., Fulton 1988; Carlebach 1992; Yapp and Hopkinson 1995). ${ }^{2}$ All recognize, of course, that even state-ofthe-art equipment in that era was inadequate for capturing and widely distributing realistic images of current or breaking news; through the lens of even the most accomplished photographer, rapid motion became a blur, brightly colored scenes lost their punch, and the world came to a halt when dusk fell. And for more than half a century after 1839 it was at first not mechanically feasible and then not aesthetically appealing to reproduce photographs in a mass-produced daily newspaper.

These historians see the salient point as intent; they argue that despite the limitations of their equipment, photographers had always been inspired to document current events or people in the news. Even daguerreotypists sometimes ventured out from the safe confines of the portrait studio to photograph suitably abeyant scenes: the train after the wreck, the building after the fire, and, accidentally, the boater after his craft overturned near the brink of Niagara Falls (Figure 3). In that case a local daguerreotypist who specialized in photographs of tourists standing motionless beside the creamy blur of the rapids was able to capture several images of the hapless

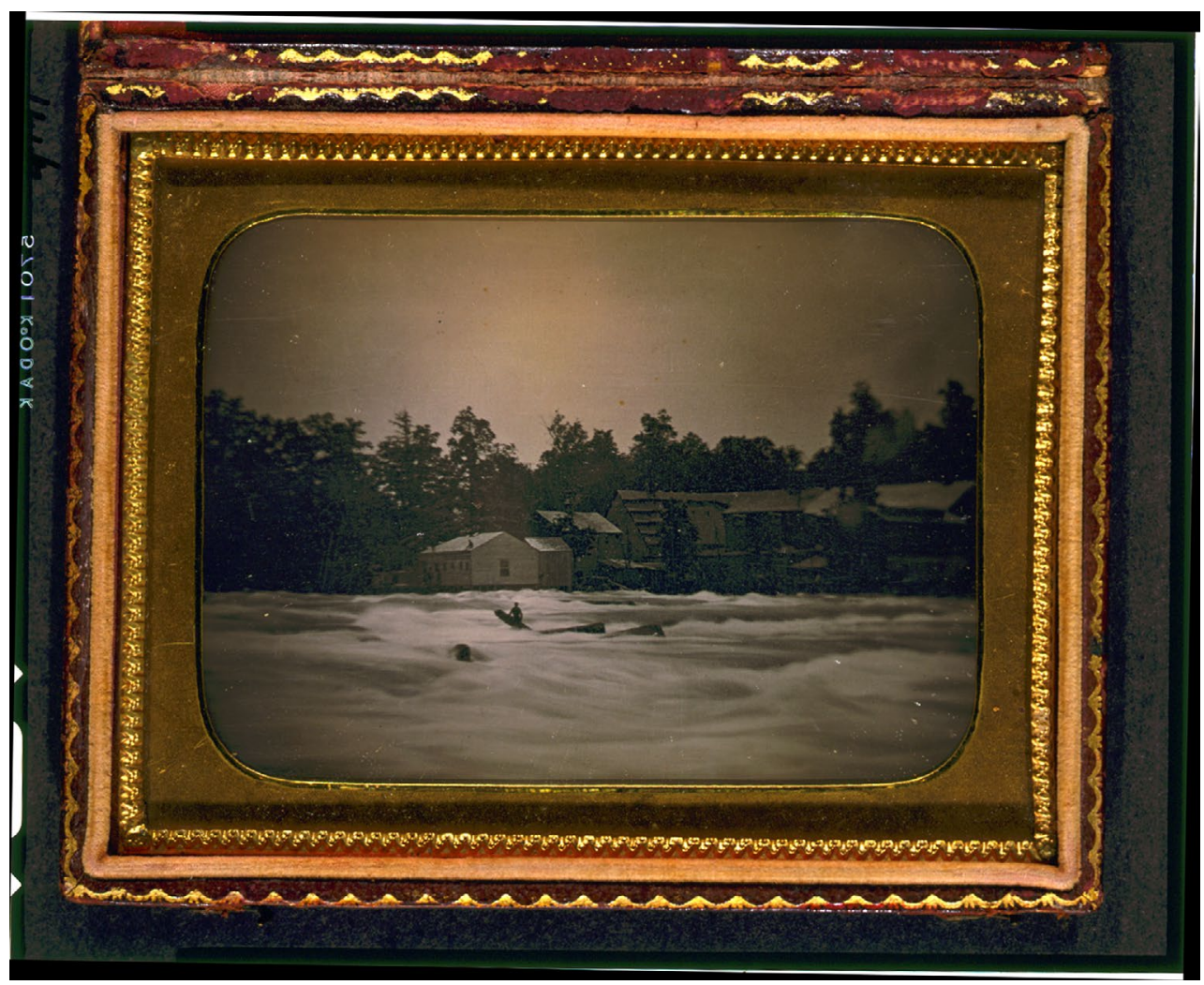

Figure 3. Platt D. Babbitt, [Joseph Avery Stranded on Rocks in the Niagara River]. Daguerreotype, I853. Library of Congress, Washington, DC. 
boater precisely because the tiny dark stick-figure was no more mobile than the tourists: he was stranded midstream on a pile-up of rocks and logs for 18 hours before finally being swept over the falls to his death, a brisk denouement that doubtless eluded the local man's lens (Werge 1890, I43-44; Rudisill 1971, 163-64). Around midcentury the advent of paper printing processes gave rise to the popular pastime of collecting stereographs and cartes de visite portraying important people or scenes. Cameras unequal to the chaos of battle still managed to bring home the anguish of war, while explorers, surveyors, and reformers hoped their images would either open minds or change them.

Yet the effort of these historians to trace a long lineage for the practice of photojournalism misses an important point. A nineteenth-century photograph of a current event bore little connection to the conventions and assumptions of the familiar information system to which most Americans would have applied the labels of "journalism" or "news."'The daily newspaper, which was the dominant form of American journalism in the nineteenth century, came almost entirely in words, not images. And while the words about current events in a newspaper were generally timely, accountable, explicit, contextualized, systematically distributed, and widely accessible, a photograph in the hand or on the wall was not reliably any of those. In fact a photograph in the hand would likely be outdone in any of those categories by the engraved illustrations of battles, fires, crimes, and other current events published in such popular weeklies as Frank Leslie's Illustrated Newspaper or Harper's, sold by Currier and Ives and other lithographic firms, or making the occasional splash in the daily penny press (Brown 2003, esp. 7-57; Czitrom 20 I0; Leja 20 I5).

As varied and sometimes whimsical as the content of newspaper could be throughout most of the nineteenth century, and as casual as ethical and professional standards remained for decades, readers knew how to categorize what they read, and were accustomed to figuring out which stories in the newspaper were intended as news stories - as timely, fact-based accounts of actual events. In the much newer medium of photography, however, which stood distinct both physically and conceptually from the large class of work labeled as journalism, consumers had little reason to mentally sequester photographs of current events into a different category from other kinds of photographs or to assume that they conveyed some higher or special level of truthfulness that other kinds could not. Whether driven by profit, by duty, by interest, or all three, photographers worked in good faith to document current events and breaking news, but they often did so by employing exactly the same kinds of tactics, manipulations, and improvements routinely used by their studio-bound colleagues.

In 1846-47, for instance, a pair of Boston daguerreotypists collaborated with a group of eminent surgeons on a series of artistically posed, dramatically lighted images, one showing a reenactment of the first operation on an anaesthetized patient, another portraying a genuine later surgery, and others apparently staged to invoke Rembrandt's famous painting of an anatomy lesson (e.g. Figure 4) - and then presented all of them as authentic historical records of medical triumphs (Lowry and Lowry 2005). In the stifling July heat on the Gettysburg battlefield, Alexander Gardner and Timothy O'Sullivan trundled corpses, weapons, and other props into more picturesque tableaux of death (Figure 5), and labeled the bodies in one image as Yanks while identifying the same bodies shot from a different angle as Rebs (Frassanito 1975, 187-92, 226-29). And Eadweard Muybridge maintained an archive of images of clouds and moons that he could insert at will into the pallid skies of the landscape photographs that brought the West to such vivid and apparently authentic life for those who would never cross the Mississippi (Solnit 2003, 47-48).

Camera images of current events functioned more like things than like journalism. Photographs at a gallery or a magic-lantern lecture offered the visitor insights into other lives, but even more, they 


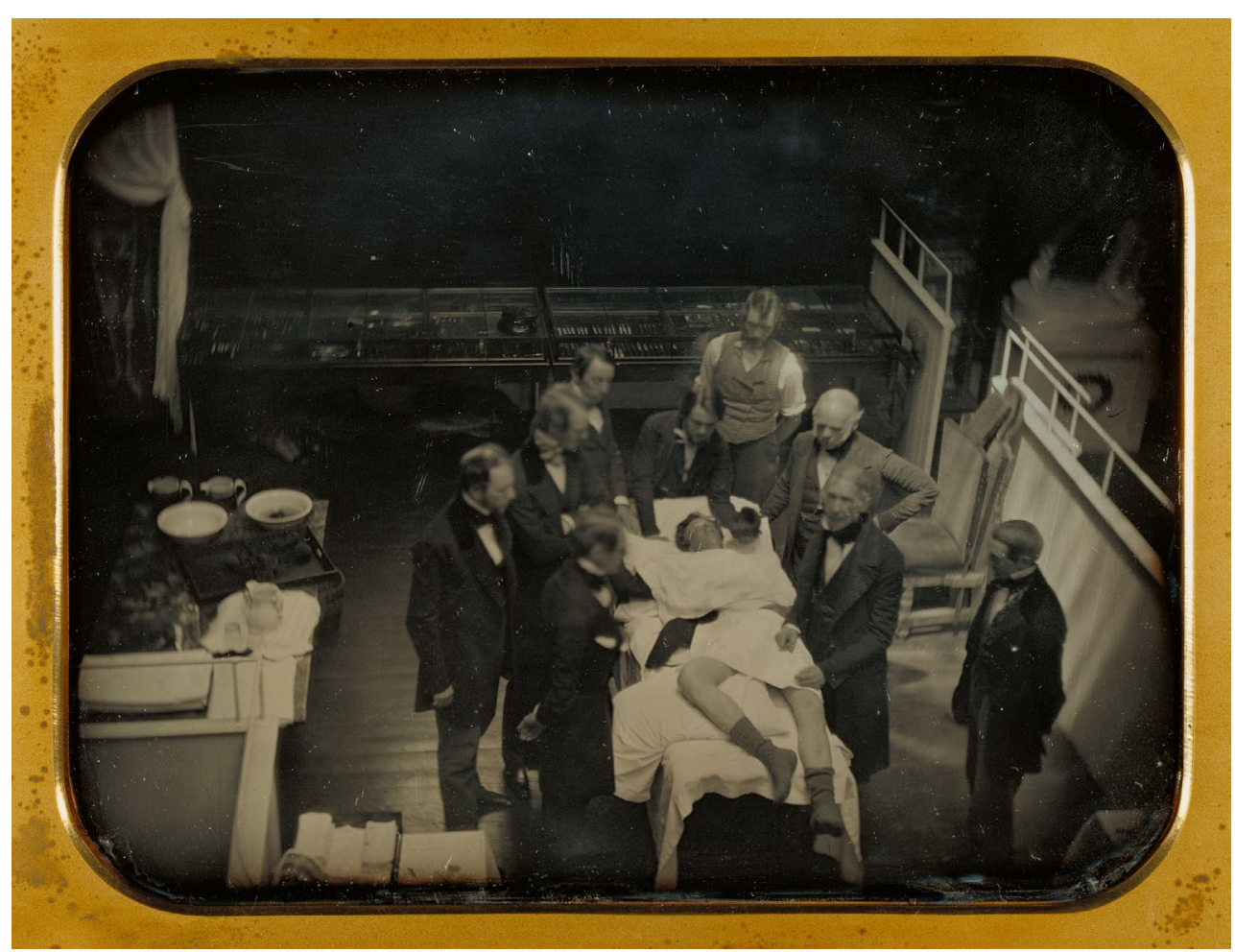

Figure 4. Southworth \& Hawes, Early Operation Using Ether for Anesthesia. Daguerreotype, I847. J. Paul Getty Museum, Los Angeles. Digital image courtesy of the Getty Open Content Program.

provided a communal, almost magical experience that all the viewers could share. Photographs propped on mantels, arranged in albums on parlor tables, or treasured in rare volumes of costly hand-mounted plates (the only way to include photographs in a published book) opened the wider world, but they also served as intimate and precious possessions, more like talismans of the world than conveyors of information about it. The value of a newspaper lay in its promise to replace itself with something equally urgent the very next day. The value of a photograph of a current event lay in its capacity to identify, preserve, and heighten that moment for all time.

This distance between what a photograph could do and what a photograph could show helps explain why even after 1880, when photomechanical reproduction became possible in the mass press, many readers and editors alike continued to prefer artists' engravings in the daily newspaper and resisted the encroachment of photographs (Barnhurst and Nerone 200 I, I I I-39; Carlebach 1997, I I-15; Harris 1990; Schuneman 1965). As accompaniments to journalistic articles, the illustrations created by the human hand, eye, and heart simply struck many observers as more visually attractive than the typical grainy, murky image produced by the halftone process, and no amount of reworking or retouching was sufficient to close the gap. The information that could be conveyed in a photograph was both prosaic and limited, moreover, compared to the worlds an artist could open up. While a human hand could gracefully disentangle the legs of a galloping horse ("Old Controversy" 1900, 2 14), arrange people into a more legible composition (Yochelson and 


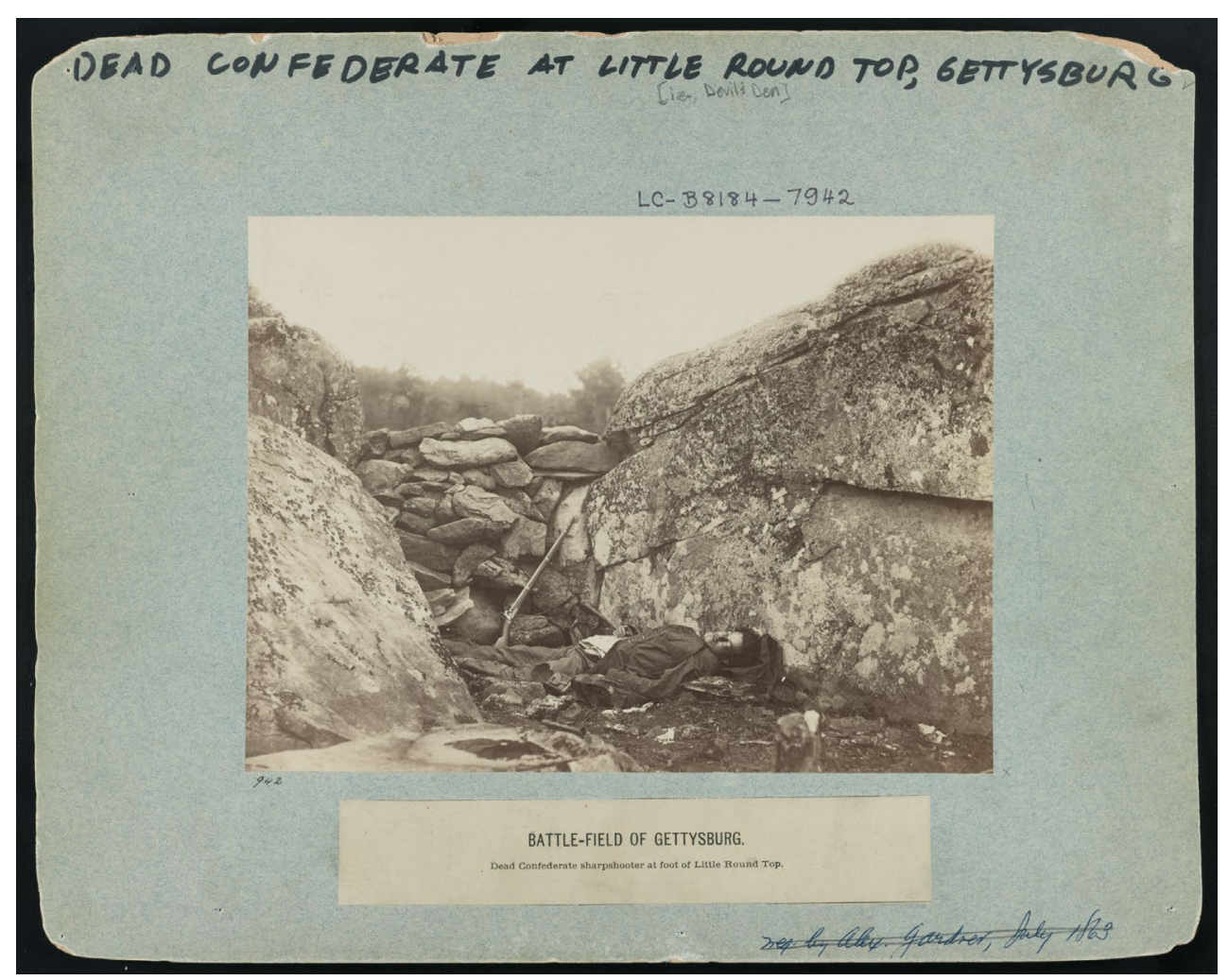

Figure 5. [Timothy O'Sullivan], Battle-Field of Gettysburg - Dead Confederate Sharpshooter at Foot of Little Round Top. Albumen print, 1863. Library of Congress, Washington, DC.

Czitrom 2014, 154-55), or render a murder scene with just enough horror (Trotti 2003, 406-407), the photographer's raw material was strictly confined to whatever scene happened to lie in front of his lens. As The Nation put it ("Perils" 1907, 29), "it must always be true that chance has a large part in producing the sensational success of popular photography ... Events perversely refuse to adapt themselves to the photographer's art."

The artistic dudgeon of The Nation, which prided itself on maintaining high standards of cultural criticism, is perhaps understandable, but even the popular Anthony's Photographic Bulletin (Carrington 1899) had to concede that "no one will deny the superiority of art to photography, and the capacity of the man with the pencil to give movement and a semblance of life to scenes that the camera simply holds in suspense. No photograph can give the impression of action that a good drawing can." When in 1897 the San Francisco Chronicle mounted an exhibition of newspaper illustrations by staff artists, it drew submissions from the biggest papers in the country and reportedly attracted enthusiastic crowds willing to spend goodly sums to take what the paper called its "poems in plain black and white" home for themselves (25 February). Another long Chronicle article on newspaper illustrators divulged without a hint of disapproval that at the New York Herald, "it is no longer the rule in the [art] department to send out an artist with a reporter who covers the story. The artists are supposed to correctly estimate the news in a story and to illustrate its salient features" (24 February). 
Art, in other words, could be more realistic than photography.

\section{Photography embraces faking}

It was in this landscape that around the turn of the twentieth century some photographers began their defiant application of the dodgy word "fake" for the processes they already had perfectly satisfactory terms like "retouching," "handwork," or "working up" to describe. Even as newspaper journalism was staking its identity upon its repudiation of the fake, and as the term took on its overwhelmingly negative odor in the general discourse, many commercial and artistic photographers kept its old playful spirit alive among themselves by applying it to a similarly modest and relatively benign range of practices.

More and more often, and just as the journalistic fakers once had, photographers argued that in their discipline, "faking" was not just legitimate but also beneficial for the consumer. In its "best sense," as one of its most ardent proponents defined the term in that enthusiastic 1902 speech before the Photographers' Association of America, it meant "simply improving the negative or the picture by any means in one's power" (Parkinson 1902, 522-23). Another advocate of the practice, the Washington photographer C. H. Claudy (1904, I I2), noted that since the word had come to carry the "suggestion of the illegitimate, and a general not-to-be-mentioned-in-polite-society air which is disagreeable to those who employ the process in what seems to them a legitimate way," he himself preferred to use more neutral terms like "retouching" or "working up." Many more, however, seemed to agree with the prominent pictorialist Alfred Maskell $(1895,295)$, who declared that he had "no quarrel with the word faking, when not used derisively or in a derogatory sense."

For some, the delicacy over faking was plain silly given the nature of the photographic process. Just as The Writer had argued back in 1887 (Hills, 154) that in newspaper journalism faking was "an almost universal practice," so too in photography "everybody 'fakes,"' wrote a well-known editor of a photography magazine (Welford I898, 572). Unlike for journalists with their notebooks, for photographers fakery was an integral element of the mechanical process they used to represent the world. In 1903 Edward Steichen (48) made the argument with the most authority in the first issue of the magisterial periodical Camera Work, where he scoffed at "the wise" who dismissed manipulated prints as "irrational photography." Because the photographer's choices behind the camera and in the darkroom inevitably affected the look of the final print, "every photograph," he argued, "is a fake from start to finish, a purely impersonal, unmanipulated photograph being practically impossible."

Newspaper fakers, who had relied entirely on their imaginations rather than on devices or contraptions in their daily work of representing the world in print, had no such mechanical excuses to fall back on. They had generally paid lip service to truth-telling, the paramount value of their profession: what they did, they said, was intended to give their readers more truth, better truth, realer truth. Not only would readers "never know," insisted The Writer, that that poor, over-the-hill "washed-out blonde" had been airbrushed into a much more "picturesque" teenage brunette (Hills I887, I 55); they'd actually prefer a version of reality that corresponded so much more closely with what they wanted to believe in the first place.

Paradoxically, however, photographers, who did use a machine for their work of representing reality, were pledging their primary allegiance to the professional values of the artist, not the technician. Indeed the increasingly close association of the concept of the fake with the aggressively "artistic" work of the pictorialist photographers offers a clue to the peculiarly insistent application of an unnecessarily disreputable label to a controversial process: it confirmed the exclusivity of their talents. For Alfred Stieglitz, for example, one of the strongest appeals of pictorial photography was his conviction that the amateur obviously couldn't do it as well as a true artist like himself could. 
He had initially lamented the introduction of the smaller and lighter "hand camera," which, he said, enabled "every Tom, Dick and Harry" to make photographs with "no work and lots of fun. Thanks to the efforts of these persons hand camera and bad work became synonymous" (1897, 19-20). The photographers who perversely embraced the ambiguous term "fake" may well have been conveying their conviction that only a special person with special skills and an artistic touch was capable of handling, let alone fully comprehending, a complex and ticklish technique whose very name would inevitably be misunderstood by the ordinary Kodak-snapping hobbyist.

C. H. Claudy, who had mildly suggested "working up" as a less "illegitimate" term than faking, was a typical all-around photographer who wrote for the trade press on a wide range of genres and practices. But his description of how he "worked up" one of his own images made clear his belief that any photographer skillful enough to manipulate a print merited a special status. "I do not believe (artistically)," Claudy explained (1904, I | 3-14), "in going out and taking haphazard pictures and finding out afterwards what they express. The man who writes a story or the painter who paints a picture without a definite idea in view, will never make more of a success than is contained in a happy fluke." Before he ever picked up his camera, therefore, he would decide what he wanted, in this case a somber wintry scene with a covering of "clammy" snow that suggested "murky, miserable weather." After capturing his image, he cropped and enlarged it, then deployed stumps, sponges, and crayons to eliminate flaws on the negative, adjust the highlights and shadows, dim the glare of the sky, and finally give the snow the "appearance of reality" by the "very delicate and judicious" erasure of its "staring whiteness." The final product was a soft grey-toned landscape redolent of both misery and murk.

A few of his fellow photographers dismissed the image as illegitimate, Claudy reported, though many more complimented him on it. But what's striking here is his own off-hand ranking of the two roles he claimed for himself. He was, clearly, a photographer, judging the look of the snow in his picture by how close it came to the "appearance of reality." But he also explicitly compared his sensibility to that of the novelist or the painter, describing how he began his project with an act of pure imagination, meticulously planned how to physically express the mood and tone he envisioned, and wielded the implements of his art with purpose and skill. First and foremost, this photographer considered himself a creative artist.

Photographers thus could accommodate the camera by correcting obvious technical flaws in the images it produced. They could overrule the camera by "improving" the image of a sitter or a scene insufficiently picturesque in the natural state. Or they could even transcend the camera by reworking the images to look as if a human hand, eye, and heart had been at work - to choose to make clear, in other words, that they had been manipulated by an expert hand. For many commercial and artistic photographers, the fake had become a measure of the professional.

\section{The news photographer confronts the fake}

On the cusp of the twentieth century, the photograph was a complicated object indeed. Sixty years after Edgar Allan Poe (1840) had marveled at the capacity of the new technology to convey "a more absolute truth," practitioners were hailing their attainment of "not literal, but spiritual and eternal truth" (Parkinson 1902, 523) and were happily applying to their pursuit of those truths the otherwise widely discredited term "faking.'The photography of current events, meanwhile, which some historians insist on calling early photojournalism, had more in common with photography than with journalism - more in common with artfully clammy snowscapes or sentimental keepsakes than with the practices, standards, and functions of the newspaper, especially of those "information" papers that at that very moment were transforming themselves into a more professionalized and 
accountable information system based squarely on the primacy of the objectively verifiable fact.

Yet the broad social and intellectual trends toward scientific realism and modernism that were helping to drive the evolution of the information papers were also leaving their mark on photography. These trends - which would influence other aspects of photography as well, notably in the movement of Stieglitz and his influential circle toward the more naturalistic artistry that would become known as "straight" photography - would help transform the currentevents photograph into a journalistic medium. Critical too were technological developments, among them the introduction of smaller and lighter cameras, faster shutters, and more versatile lenses and flashes, which permitted the capture of more lifelike images. Improvements to plates, papers, and roll film simplified the developing process, and the growth of syndicates like George Bain's offered systematic distribution over established networks. And the ever-increasing ranks of camera hobbyists, as embarrassing as their artless snapshots might seem to the proud professional, were also driving changes in the public's attitudes toward photography. As a former president told the Photographers' Association in 1899, "the work of the camera is now regarded by the people as the embodiment of the truth ... Waiting for the truth and waiting for the report of the lens of the camera are one and synonymous" (Hayes 1899, 232; see also Barnhurst and Nerone 200 I, 136-39; Orvell 1989, 198-206; Carlebach 1997, 30-36).

In the trade press the commentary gradually grew more confident about the birth of a new profession and the emergence of a new category of photography. Just three years after the San Francisco Chronicle celebrated the prose poems of the newspaper artist, a writer for the American Annual of Photography was arguing that the sketch artist who supplied newspaper illustrations from his imagination has been "supplanted" by the photographer. All over the world, he went on, "the newspapers are sending photographers to gather the news with camera as well as with pen.
These bright, active, daring young men are now recognized as news-photographers, and their work is known as news-photography" (Willets 1900, 53).

The newly coined labels clearly strove to connect this nascent genre of photography to the objective, professionalized newspaper and to the tasks of verifying facts and providing readers with an additional and important kind of intelligence, a distinct new category of visual information: the pure, impersonal, unadulterated, unimproved, real truth that was unmanipulated by the intervention of a human hand. The camera "tells news-stories truthfully," the American Annual continued:

None of the inaccuracies of the pen, no fiction, no exaggerating of facts, no news that is not news. The camera does not lie. It shows people as they really look, reproduces scenes with realistic exactness. No chance here for the city editor to make the ugly young woman suicide a beauty, no need of "faking" a picture of events that are happening on the other side of the world. (Willets 1900, 54)

Another writer attributed the changes to the demands of the public - just as the defenders of faking had.

We are living in an age which ... demands a very large percentage of truth in its newspaper illustrations, and the truth of the camera is undeniable ... At times truth is ugly; nevertheless, the present-day requirements are "undisputable facts," and a "true" photograph is distinctly preferable to a dozen sketches, no matter what the subject may be. (Everhard 1907, 373)

"A very popular novelist," he concluded, "has said that 'a photograph is a speech in print. It is the truth done by machinery'. And these words sum up the qualifications of the 'newsy' photograph" (374). ${ }^{3}$

This claim that news photographers were doing truth by machinery, however, had a hurdle to surmount: the decades' worth of claims by other photographers that what they were doing was art by machinery. Yes indeed, the photographic fakers 
had assured their public, we are artists. It's true we use machines, but our cameras are no different from paintbrushes and chamois cloths; they are the means by which we deploy our skills to create and beautify and improve, and you can trust us as professionals to recognize and control the fact that, as Steichen (1903) put it, "every photograph is a fake from start to finish."

For the new photographers of news, a different task loomed: to remechanize their machines. One of their tactics was to humanize themselves. Unlike the new professionalizing print journalists, who were erasing their individuality, subsuming their opinions, and reworking their prose style into something more like that of an algebra textbook in the effort to appear as neutral observers, news photographers worked hard to identify and explain the human virtues, talents, and qualities that now distinguished them. Their "berth is no sinecure," the American Annual (Willets 1900,55) pointed out; they had to "have a fine nose for news, must not flinch where others flee, must always look alive, give no quarter even to people who do not wish to be photographed" (57). They had to be adventurous; the true news photographer, as the popular Munsey's Magazine reported, was willing to go anywhere and do anything to show the public the way things really were.

These knights of the camera travel on foot, by horse, by balloon, by automobile, by camel caravan. They dare fever in the lowlands and death on mountain heights... In the jungles of the "big game country" they explode their flash-lights in the very lair of the night-prowling beast; and by day they rig their tripod in the runway of the rhinoceros. (Johnston 191 I, 797)

Now the very quality that had once relegated the photograph to second place behind the artist's illustration was being touted as its signature virtue. An artist could have tossed off his sketch of a rhinoceros while sitting comfortably in his armchair at home, and no one would have been the wiser. A photographer, however, had no such leeway; he had to have been there, and the fact that his raw material was strictly confined to whatever scene happened to lie in front of his lens was no longer a constraint but a guarantee of his enterprise and skill. To bring home the "live stuff" his paper demanded, advised Camera and Dark-Room, the photographer had to be "diplomatic, quick of wit and action, of infinite patience, and prepared to stalk his subject as intelligently as a hunter stalks his game"; he should be unafraid to venture "into places where angels would prefer to send their regrets" ("Some Phases" 1905, 290). And in a celebration of the enterprise of the photographers of New York City, World's Work (Page 1907, 392) noted that one had spent two days on the rooftops around Times Square looking for the best vantage for covering the election-night crowds, another had stayed so long on the racetrack to get a "head-on" shot that he had almost been run down by the horses, a third had crawled into a drain, and yet another had risked his neck carrying his entire kit up a cable on the Brooklyn Bridge.

While news photographers worked hard to present themselves as daring, diplomatic, and quickwitted, they also made a clear case for what they were not. "The news-photographer must sacrifice art for subject-matter," cautioned one veteran.

The subject is everything; the excellence or the demerits of the photograph count for nothing for or against the worker. The idea is, picture the news, whether the pictures are artistic or not ... News-photography is news reporting. (Willets 1900, 58-59)

What mattered was the forthright engagement by photographers with places and events in the real world, not their artistic cunning with pencil and chamois in the darkroom. Artistry was the enemy of authenticity, and the intervention of a human hand into any depiction of the real thing could only make it less realistic.

And here is where the photographic fake played its most important role in the evolving social work of photojournalism: it was publicly repudiated by the emerging profession. By 
rejecting the fake, news photographers focused public attention on what they did and, even more importantly, what they would not do. Just as the "serious" print reporters had used the epithet "faker" to relegate their embarrassing yellow colleagues to a second-class category of the unprofessional and the crude, news photographers branded the photo-fakers as the embodiment of everything they were not, and proved their own purity by loudly and frequently blasting the impurities of their more disreputable brethren. Just as the newspaper reporters had done, the news photographers strengthened their case by highlighting the most exaggerated fakes they could find, while virtually ignoring those modest artistic tweaks to snow or sky that "everyone" did and most excused. Trade journals delighted in exposing the newspaper that used the picture of the wrong city on fire (Page 1907, 392), or the one that erased a whole crowd of onlookers out of a photograph of a martiallooking King of England inspecting a Maxim gun ("King" 190I), or the one that searched out a young woman willing to accept ten dollars to pose as a suicide victim by allowing herself to be strung up by the neck for a few seconds while the camera clicked ("Experiences" 1905, 202). But "the fake photo is generally discredited in your really high-class newspaper," that article assured its readers in conclusion; the "better class of papers" never uses or countenances them (205).

The fake, then, was still the measure of the professional, but where once it was the professional photographers (and before them the serious journalists) who assured the public that they alone had the skill and imagination to fake, now it was the professionals who were assuring the public that they alone had repudiated the practice and could be trusted never to fake. News photographers "are the 'men on the job,' wherever their 'job' may be, and whatever its difficulties and dangers," the Munsey's article concluded. "They are the real reporters of the world's realism" (Johnston 191।,797).
Reporting the world's realism, it had now become clear, required of photojournalists an approach similar in many ways to that of the professionalizing print reporters. Although newspaper journalists submerged their individual identities and personalities behind the veil of newsprint while news photographers celebrated their personal heroics, otherwise the reporters with the cameras followed the same rules as the ones with the pencils. They valued observation over involvement and disinterest over artistry. They resisted the temptation to embroider and improve on what they observed no matter what its dramatic or scenic flaws. They rejected the visible intervention of the human hand and presented themselves as every bit as authoritative and authentic as a machine. News photographers were, in short, defining themselves as entirely different from the artistic and commercial colleagues whose battle-cry of "I believe in faking" fundamentally disqualified them from claiming that they had achieved the special kind of truth - the more realistic, more complete, and truer truth accessible only through journalistic methods.

In some ways this century-old debate over the authenticity and integrity of the photograph feels crisply contemporary. The prevalence of digital cameras and the popularity of image-editing software have thrown professional photojournalists into a renewed struggle to establish and publicize the standards that guide their work and differentiate it from everyone else's. The results, however, have been mixed. The prestigious World Press Photo competition, for instance, which is administered annually by a non-profit foundation based in Amsterdam, has in recent years endured so many controversies about the possible staging, manipulation, or too-vigorous retouching of entries that it's become a sort of Ground Zero for the professional community for arguments over the permissible boundaries for editing news photographs. After $20 \%$ of the finalists in the 2015 competition were disqualified, most of them for unacceptable levels of post-processing, World Press Photo published on its website a detailed code 
of ethics that specifically addresses the question "What counts as manipulation?" In the following year's contest the disqualifications did drop - but, as the photography blog PetaPixel reported (2 March 2016), they still amounted to $16 \%$ of the submissions.

Often recurring in this century's conversation is a word familiar from last century's debate.

During the dispute over whether the grand-prize winner for the 2013 World Press Photo contest, Paul Hansen's "Gaza Burial," was overprocessed, for instance, the well-reported technology blog ExtremeTech ran an exposé ( 13 May 2013) initially entitled "How the 2013 World Press Photo of the Year was Faked with Photoshop." Even after the headline was softened to read "Was the 2013 World Press Photo of the Year Faked with Photoshop, or Merely Manipulated?" ExtremeTech was deliberately using that blunt four-letter word to declare its disdain for the practice and, like the pioneering news photographers of a century ago, to distinguish professional photojournalism from unacceptable work. Defenders of Hansen's photograph, meanwhile, often responded in the same terms, as in an article on the Wired website (I6 May 2013) headlined "'Fake'World Press Photo Isn't Fake, Is Lesson in Need for Forensic Restraint."

Yet even as photojournalists struggle not just to define but also to defend their standards in the face of persistent public skepticism, other kinds of photography are flourishing. On the one hand, as financially troubled news organizations jettison their staff photographers in favor of the ubiquitous citizen journalist with a smartphone camera in his or her pocket, even a former head of Magnum Photos and two-time former Chairman of World Press Photo can publicly state, on the Editorial Photographers United Kingdom \& Ireland blog (I August 20 I0), that "we owe it to our children to tell them that the profession of 'photojournalist' no longer exists." Or to interpret that statement another way, if no one is a photojournalist, then everyone is.
On the other hand, many amateur or artistic photographers see faking - under the updated label "Photoshopping," which routinely appears in standard dictionaries as a verb - as a playful form of expression and creative social commentary, and gleefully share such online images as a grinning, gun-toting Sarah Palin wearing a stars-and-stripes bikini or Hillary Clinton's face framed by Donald Trump's hair and topping Donald Trump's body. Photoshopped images can also be mischievous (sharks swimming down hurricane-flooded urban streets) or malicious (the Republican presidential hopeful Marco Rubio raptly shaking hands with President Obama, on a website reportedly paid for by Rubio's rival Ted Cruz) or simply deliciously maladroit (see almost any fashion magazine). And exposing the other guy's mischievous or malicious or maladroit Photoshopping has become a highly competitive parlor game, complete with "photo forensics" software, tell-all websites like Snopes.com, tongue-in-cheek memes like "this looks shopped," and popular Twitter hashtags like \#photoshopfail, all designed to announce to the world that I have seen through your fake. If everyone is a faker, then no one is.

A century ago, members of the emerging profession of photojournalism worked to distinguish themselves by suggesting that their standards and work ethic gave them access to a special kind of truth. Today, the declining profession of photojournalism seems overshadowed by an exuberant community of manipulators, Photoshoppers, artists, provocateurs, and fakers who vigorously debate their own special understanding of truth.

\section{Acknowledgements}

The author wishes to thank Dan Czitrom and Michael Schudson for their helpful comments.

\section{Disclosure statement}

No potential conflict of interest was reported by the author. 


\section{Notes}

I. The popular traveling museum exhibition Faking It that drew crowds in New York, Washington, and Houston in 2012-13 (see Fineman 2012) took an expansive view of the meaning of "fake," embracing every kind of manipulated image from tinted daguerreotypes to surrealist works of art to snapshots with the subject's political rivals erased. I am confining myself much more narrowly to the kinds of beautifying, retouching, and artistic expressiveness that were explicitly labeled "faking" in this era.

2. Keller $(1990,285)$ notes that "until ca. 1885 the history of photography does not know of a single photographer who specialized exclusively in news reporting." The term "photojournalism" itself came into use in the 1920s and 1930s with the advent of picture magazines such as Life (Griffin 1999, 122).

3. The passage by the "very popular novelist" he apparently refers to, from F. Marion Crawford's Katharine Lauderdale ( 1894, 2 I I), actually makes the opposite point, arguing that a photograph is much less expressive than a painting.

Tucher is a former journalist who writes on the history of journalism and on the evolution of the conventions of truth-telling. Besides her many articles in scholarly journals and popular publications, she is the author of Happily Sometimes After: Discovering Stories from Twelve Generations of an American Family (University of Massachusetts Press, 2014) and Froth and Scum:Truth, Beauty, Goodness, and the Ax-Murder in America's First Mass Medium (University of North Carolina Press, 1994).

\section{References}

Bain, George Grantham. I 894. "Newspaper 'Faking'.” Lippincott's Monthly Magazine 54: 274-278.

Barnhurst, Kevin G., and John Nerone. 200I. The Form of News: A History. New York: Guilford.

Brown, Joshua. 2003. Beyond the Lines: Pictorial Reporting, Everyday Life, and the Crisis of Gilded Age America. Berkeley: University of California Press.

Carlebach, Michael L. 1992. The Origins of Photojournalism in America. Washington, DC: Smithsonian Institution Press.
Carlebach, Michael L. 1997. American Photojournalism Comes of Age. Washington, DC: Smithsonian Institution Press.

Carrington, James B. 1899. "The Artist and the Camera as Recorders of History." Anthony's Photographic Bulletin 30: 103.

Claudy, C. H. 1904. "Working Up a Picture." Photo Era I3: | $12-1 \mid 4$.

Connery, Thomas B. 201 I. Journalism and Realism: Rendering American Life. Evanston, IL: Northwestern University Press.

Crawford, F. Marion. 1894. Katherine Lauderdale. New York: Macmillan.

Czitrom, Daniel. 2010. "Currier \& Ives and the Emergence of Mass Culture." In The Legacy of Currier \& Ives: Shaping the American Spirit, edited by the D'Amour Museum of Fine Arts, 26-32. Springfield: Springfield Museums Association.

Dreiser, Theodore. 2000. Newspaper Days: An Autobiography. Edited by T. D. Nostwich. Santa Rosa, CA: Black Sparrow Press.

Everhard, John. 1907. "Photography for the Press-The 'News' Photograph." Wilson's Photographic Magazine 44: 373-377.

"Experiences of a Newspaper Photographer, By One of Them: Part IV."' 1905. Photographic Times 37: 20 I-205.

Fineman, Mia. 2012. Faking It: Manipulated Photography before Photoshop. New York: Metropolitan Museum of Art.

Forde, Kathy Roberts, and Katherine A. Foss. 2012."'The Facts-the Color!-the Facts': The Idea of a Report in American Print Culture, I885-1910." Book History I5: |23-|5|.

Frassanito, William A. 1975. Gettysburg: A Journey in Time. New York: Charles Scribner's Sons.

Fulton, Marianne. 1988. Eyes of Time: Photojournalism in America. Boston, MA: Little, Brown / International Museum of Photography at George Eastman House.

Griffin, Michael. 1999. "The Great War Photographs: Constructing Myths of History and Photojournalism." In Picturing the Past: Media, History, and Photography, edited by Bonnie Brennen and Hanno Hardt, 122-157. Urbana: University of Illinois Press. 
Harris, Neil. 1990. "Iconography and Intellectual History: The Halftone Effect." Chap. 14 in Cultural Excursions: Marketing Appetites and Cultural Tastes in Modern America. Chicago, IL: University of Chicago Press.

Hayes, C. M. 1899. "Address [Before the Photographers' Association of America]." Anthony's Photographic Bulletin 30: $231-233$.

Hickmott,W. J. I 897. "A Plea for Retouching.” American Annual of Photography and Photographic Times Almanac I I: 80-83.

Hills, William H. I887. "Advice to Newspaper

Correspondents IV: 'Faking'.' Writer I: | 54-|56.

Hinton, A. Horsley. I 898. "Faking and Control in Principle and Practice." Photographic Times 30: 67-74.

Johnston, William Allen. 191 I. "Crucial Moments Caught by the Camera." Munsey's Magazine 45: 786-797.

Jussim, Estelle. 1981. Slave to Beauty: The Eccentric Life and Controversial Career of F. Holland Day, Photographer, Publisher, Aesthete. Boston, MA: David R. Godine.

Kaplan, Louis. 2008. The Strange Case of William Mumler, Spirit Photographer. Minneapolis, MN: University of Minnesota Press.

Keller, Ulrich. 1990. "Photojournalism Around 1900:The Institutionalization of a Mass Medium." In Shadow and Substance: Essays on the History of Photography in Honor of Heinz K. Henisch, edited by Kathleen Collins, 283-303. Bloomfield Hills, Mich.: Amorphous Institute Press.

“The King in a Faked Picture." 1901. The Journalist 29: 577.

Leja, Michael. 2004. Looking Askance: Skepticism and American Art from Eakins to Duchamp. Berkeley: University of California Press.

Leja, Michael. 20I5. "News Pictures in the Early Years of Mass Visual Culture in New York: Lithographs and the Penny Press." In Getting the Picture:The Visual Culture of News, edited by Jason E. Hill and Vanessa R. Schwartz, |46-| 53. London: Bloomsbury.

Lowry, Bates, and Isabel Lowry. 2005. "Simultaneous Developments: Documentary Photography and Painless Surgery." In Young America: The Daguerreotypes of Southworth \& Hawes, edited by Grant B. Romer and Brian Wallis, 75-88. New York: International Center of Photography.

Maskell, Alfred. I895. "On Pictorial Photography-The Old and the New." Anthony's Photographic Bulletin 26: 293-296.
Morgeneier, Robert. 1873. "Ideas on Negative Retouching." Philadelphia Photographer, Sept. I: 451.

Novak, Daniel A. 2008. Realism, Photography, and Nineteenth-Century Fiction. Cambridge: Cambridge University Press.

"An Old Controversy." 1900. St. Louis and Canadian Photographer 24: 21 I-214.

Orvell, Miles. 1989. The Real Thing: Imitation and Authenticity in American Culture, 1880-1940. Chapel Hill: University of North Carolina Press.

Page, Arthur W. 1907. "Adventures of Daring Photographers." World's Work 10: 391-403.

Parkinson, Morris Burke. 1902." The Idiosyncrasies of the Customer and a Word About Faking." American Amateur Photographer 14: 517-523.

"The Perils of Photography." 1907. The Nation, July I I, 28-29.

Poe, Edgar Allan. I 840. “The Daguerreotype." Alexander's Weekly Messenger, Jan. 15: 2.

Roggenkamp, Karen. 2005. Narrating the News: New Journalism and Literary Genre in Late Nineteenth-Century American Newspapers and Fiction. Kent, $\mathrm{OH}$ : Kent State University Press.

Rudisill, Richard. 1971. Mirror Image: The Influence of the Daguerreotype on American Society. Albuquerque, NM: University of New Mexico Press.

Schudson, Michael. 1978. Discovering the News: A Social History of American Newspapers. New York: Basic.

Schuneman, R. Smith. 1965. "Art or Photography: A Question for Newspaper Editors of the 1890s." Journalism Quarterly 42 (Winter): 43-52.

Shi, David E. 1995. Facing Facts: Realism in American Thought and Culture, 1850-1920. New York: Oxford University Press.

Shuman, Edwin L. 1894. Steps Into Journalism: Helps and Hints for Young Writers. Evanston, IL: Evanston Press Co.

Snelling, H. H. I872. "Retouching Negatives." Philadelphia Photographer, March I, 71-72.

Solnit, Rebecca. 2003. River of Shadows: Eadweard Muybridge and the Technological Wild West. New York: Penguin.

"Some Phases of Newspaper Photography." 1905.

Camera and Dark-Room 8: 290-294. 
"The Spectator." 1901. Outlook, Feb. 23, 437-439.

Steffens, Lincoln. (1931) 2005. Autobiography. Reprint, Berkeley: Heyday Books.

Steichen, Edward. 1903. "Ye Fakers." Camera Work I (Jan.): 448.

Stieglitz, Alfred. I 897. "The Hand-Camera-Its Present Importance." American Annual of Photography and Photographic Times Almanac I I: 19-27.

Taft, Robert. 1938. Photography and the American Scene: A Social History, 1839-1 889. New York: Macmillan.

Trotti, Michael Ayers. 2003. "Murder Made Real:The Visual Revolution of the Halftone." Virginia Magazine of History and Biography II I: 379-410.

Tucher, Andie. 200 I. "In Search of Jenkins: Taste, Style, and Credibility in Gilded-Age Journalism." Journalism History 27 (2): 50-55.

Tucher, Andie. 2006. "Reporting for Duty: The Bohemian Brigade, the Civil War, and the Social Construction of the Reporter." Book History 9: |31-157.

Tucher, Andie. 20 13."The True, the False, and the "Not Exactly Lying': Making Fakes and Telling Stories in the Age of the Real Thing." In Literature and Journalism: Inspirations, Intersections, and Inventions from Ben Franklin to Stephen Colbert, edited by Mark Canada, 9 I-। I 8. New York: Palgrave Macmillan.
Walker, John Brisben. 1898. "Some Difficulties of Modern Journalism." Cosmopolitan, Jan., 328.

Welford, Walter D. I898. "Individuality vs. Standards." Photographic Times 30: 570-572.

Werge, John. 1890. The Evolution of Photography. London: Piper \& Carter.

Willets, Gilson. 1900. "News-Photography." American Annual of Photography and Photographic Times Almanac I4: 53-60.

Yapp, Nick, and Amanda Hopkinson. 1995. 150 Years of Photo Journalism: The Hulton Getty Picture Collection. Cologne: Könemann.

Yochelson, Bonnie, and Daniel Czitrom. 2014. Rediscovering Jacob Riis: Exposure Journalism and Photography in Turn-of-the-Century New York. Chicago, IL: University of Chicago Press. 